\title{
SnoRNA in Cancer Progression, Metastasis and Immunotherapy Response
}

\author{
Jildou van der Werf $\mathbb{D}^{\mathrm{D}}$, Chue Vin Chin and Nicholas Ian Fleming * \\ Department of Pathology, University of Otago, Dunedin 9016, New Zealand; \\ jildou.vdwerf@outlook.com (J.v.d.W.); chuevin@gmail.com (C.V.C.) \\ * Correspondence: nicholas.fleming@otago.ac.nz
}

Citation: van der Werf, J.; Chin, C.V.; Fleming, N.I. SnoRNA in Cancer Progression, Metastasis and Immunotherapy Response. Biology 2021, 10, 809. https://doi.org/ 10.3390/biology10080809

Academic Editor: Loredana Moro

Received: 30 July 2021

Accepted: 17 August 2021

Published: 20 August 2021

Publisher's Note: MDPI stays neutral with regard to jurisdictional claims in published maps and institutional affiliations.

Copyright: (c) 2021 by the authors. Licensee MDPI, Basel, Switzerland. This article is an open access article distributed under the terms and conditions of the Creative Commons Attribution (CC BY) license (https:/ / creativecommons.org/licenses/by/ $4.0 /)$.
Simple Summary: A much larger number of small nucleolar RNA (snoRNA) have been found encoded within our genomes than we ever expected to see. The activities of the snoRNAs were thought restricted to the nucleolus, where they were first discovered. Now, however, their significant number suggests that their functions are more diverse. Studies in cancers have shown snoRNA levels to associate with different stages of disease progression, including with metastasis. In addition, relationships between snoRNA levels and response to immunotherapies, have been reported. Emerging technologies now allow snoRNA to be targeted directly in cancers, and the therapeutic value of this is being explored.

Abstract: Small nucleolar RNA (snoRNA) were one of our earliest recognised classes of non-coding RNA, but were largely ignored by cancer investigators due to an assumption that their activities were confined to the nucleolus. However, as full genome sequences have become available, many new snoRNA genes have been identified, and multiple studies have shown their functions to be diverse. The consensus now is that many snoRNA are dysregulated in cancers, are differentially expressed between cancer types, stages and metastases, and they can actively modify disease progression. In addition, the regulation of the snoRNA class is dominated by the cancer-supporting mTOR signalling pathway, and they may have particular significance to immune cell function and anti-tumour immune responses. Given the recent advent of therapeutics that can target RNA molecules, snoRNA have robust potential as drug targets, either solely or in the context of immunotherapies.

Keywords: snoRNA; cancer; mTOR; ribosome; immunotherapy; immune checkpoint inhibitors

\section{Introduction}

Small nucleolar RNA (snoRNA) have a fascinating history, dating back to the very first years of RNA biology. For that same reason, they were largely ignored by cancer researchers until genome sequencing revealed that many more exist than initially expected. In a recent assessment, at least 2000 snoRNA were annotated within our human genomes [1].

Early work rightly determined that many snoRNAs function within the nucleolus, where they were first found, and that they target post-transcriptional modifications into ribosomal RNAs (rRNA). This in turn, supports the generation of robust ribosome ribonucleoprotein (RNP) complexes. However, their updated number and increased appreciation for non-coding RNA functionality has led to a reassessment of their activities. Presently, multiple reports reveal a functional diversity amongst these molecules. It is now clear that their influence extends well beyond the nucleolus into the wider nucleus and even cytoplasm. Moreover, it appears that snoRNA are impactful in health and disease, and not least in cancer biology. Recently, we have seen multiple reports that implicate these molecules in the establishment, progression and metastasis of cancers. Perhaps more importantly, we have seen that they are significant regulators in the immune system that fights against them. 


\section{SnoRNA: Long Known Regulators of Ribosomal RNA Maturation}

The name snoRNA was coined in 1982 [2], following foundation studies by a number of investigators, including the eminent cancer researcher Bob Weinberg [3]. Within the nucleus, a series of small nuclear RNAs (snRNAs) were identified as being facilitators of mRNA splicing (U1-U6), and molecules specific to nucleolus (snoRNA) were named (e.g., U3, 5.4, B1, B2, 7.1 and 7.2) [2,4]. Strictly speaking, the term snoRNA originally referred only to those small nucleolus RNAs, but in subsequent years it has evolved to encompass a small group of related RNA structures that, in many cases, operate in other nuclear structures and even the cytoplasm. The classic snoRNA's fall into three major groups: first, the C/D box snoRNAs (SNORDs) are typically 60 to $90 \mathrm{nt}$ long and contain C/D box motifs (C: RUGAUGA and D: CUGA). Next, the H/ACA box snoRNAs (SNORAs) range from 120 to $140 \mathrm{nt}$ and include H/ACA box motifs (H: ANANNA and ACA: ACA) [5]. Third, the small Cajal body-specific RNAs (SCARNAs) are more variable in length and include the $\mathrm{C} / \mathrm{D}$ and $\mathrm{H} / \mathrm{ACA}$ motifs in varying combinations (Figure 1). The SNORDs and SNORAs typically reside in the nucleolus where they are incorporated into RNPs that modify rRNA, and the SCARNAs localise to Cajal bodies where they are thought to help modify U1 to U6 [6]. However, a growing list of variants have emerged, and currently, the snoRNA class should be considered a spectrum of molecules incorporating these motifs [7] (Figure 1). For example, Chen et al. recently described long non-coding RNA (lncRNA) species that use C/D box structures as stabilisation alternatives to $5^{\prime}$ caps and polyadenylation [8-10]. Further, a growing series of reports indicate that these molecules are subject to significant additional processing so that multiple smaller snoRNA-derived RNAs exist (sdRNAs), sometimes trimmed down to discrete $\mathrm{C} / \mathrm{D}$ boxes [11] or instead down to sizes similar to microRNA (miRNA) and piwi-interacting RNA (piRNA) [12,13].

Functionally, the C/D box is essential for SNORD snoRNAs to form a hairpin loop and interact with the RNP proteins NOP58, NOP56 and SNu13, together with the RNA methyl transferase fibrillarin (FBL), which then post-transcriptionally methylate rRNA at sites that complement sequences within the snoRNA [14,15]. Likewise, H/ACA box structures enable SNORA molecules to form RNPs with NOP10, NHP2, GAR1 and dyskerin pseudouridine synthase 1 (DKC1), as well as to induce pseudouridation in rRNAs using complementarity to the snoRNA $[16,17]$ (Figure 1). In the human genome, snoRNA genes are generally encoded within introns of larger host genes, either specifying proteins or larger lncRNA, which in some cases appear dedicated to the purpose. Well known examples include growth arrest-specific transcript 5 (GAS5), ZNFX1 antisense RNA 1 (ZFAS1) and a series of at least 27 genes named small nucleolar RNA host genes 1-32 (SNHG1-32). However, the most exciting aspects of the snoRNA field is that there are many more snoRNA genes than previously thought, and the list of processes they influence is expanding. Recent efforts to consolidate records for these (e.g., RefSeq, Ensembl, RNAcentral, Rfam, snOPY) determined that we have at least 461 identifiable unique SNORD genes, 246 SNORAs and 21 SCARNAs within our genomes. Due to gene duplication, there is at least 2064 separate snoRNA genes [1,7]. Significantly, there appear to be many more snoRNA than those required to modify known nuclear targets such as rRNA, and more than half have no elucidated function, i.e., they are "orphan snoRNA". 


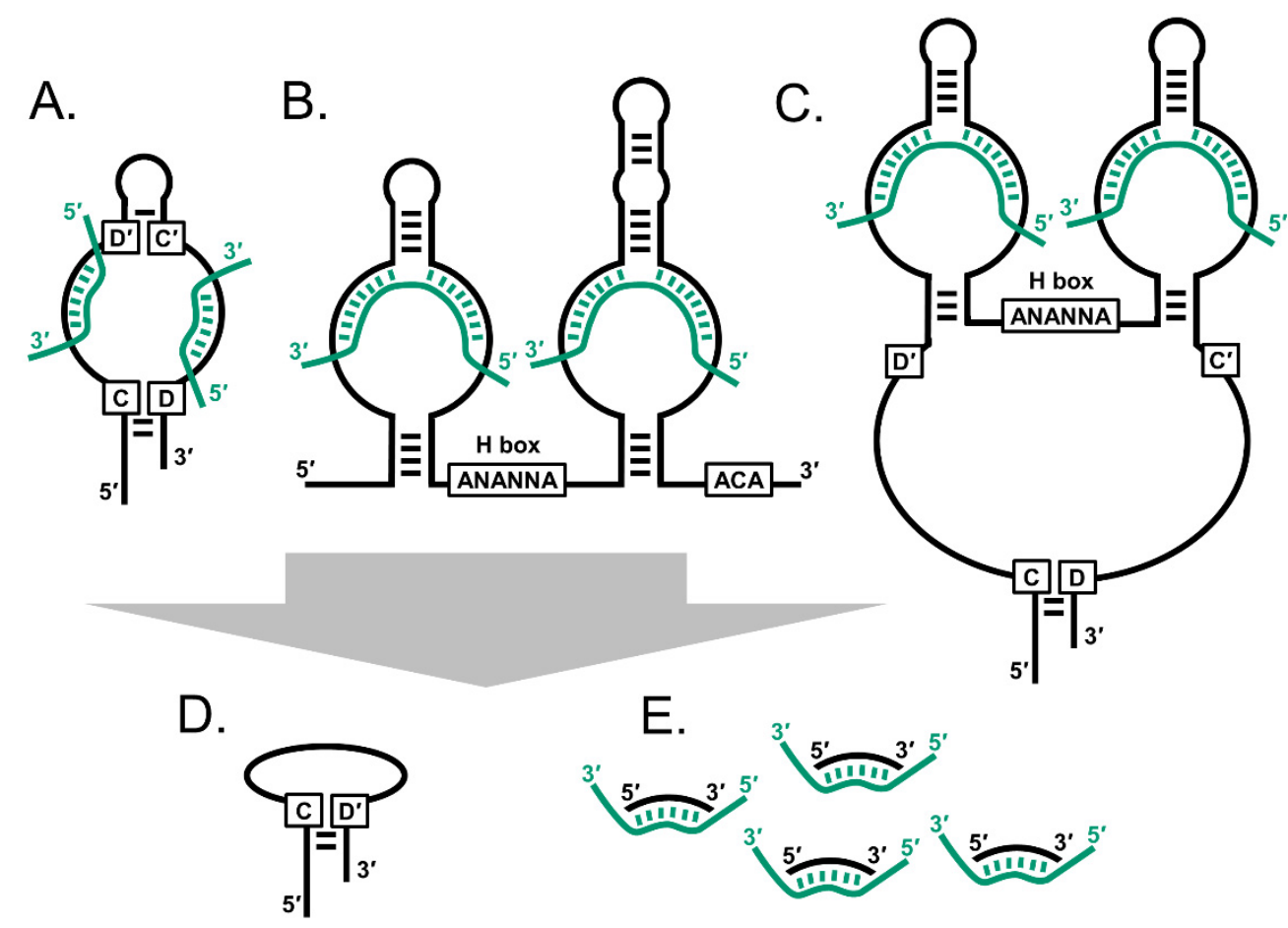

Figure 1. The snoRNAs are an interrelated family of small non-coding RNA. (A) C/D box snoRNAs (SNORDs) typically have two sets of C/D boxes that mediate hairpin structures. (B) H/ACA box snoRNAs (SNORAs) have an H box and ACA motifs. (C) Small Cajal body-specific RNAs (SCARNAs) have combinations of the two motif sets. Smaller snoRNA derived species include (D) C/D box-like snoRNAs and (E) snoRNA-derived RNAs (sdRNAs). Black strands: snoRNA; green strands: rRNA, spliceosomal snRNA and mRNA.

\section{The Wider Biological Activities of snoRNA Extend Well beyond the Ribosome}

Evidence that snoRNA do more than modify nuclear RNAs comes from multiple lines of study, including human developmental genetics, chromatin studies and cancer biology. The genetic conditions Prader-Willi syndrome (PWS) and Angelman syndrome (AS) have long been key topics in human genetics as they result from deletions at the same imprinted locus, and differentially manifest according to parent of origin [18]. However, it turns out that they are more remarkable still thanks to the involvement of snoRNA. As with most conditions caused by genomic deletions, initial attempts to define the critical altered region suggested that multiple genes may contribute [18], yet, as further data reduced the region for PWS and AS, focus shifted to a snoRNA host gene called SNHG14 [19]. SNHG14 occupies a sub-locus called SNURF-SNURPN and encodes 47 copies of SNORD115, 29 copies of SNORD116 and a number of single copy SNORDs, e.g., SNORDs 64, 108, 109A and 109B [19]. In establishing which of the SNORDs was responsible, several mechanistic studies first pointed to the SNORD115 family [20,21]. Then later, Sahoo et al. examined patients with smaller deletions and concluded that loss of SNORD116 copies was the critical event [22-24]. Importantly, mouse models were generated to test the effects of SNORD116 loss. Although the phenotypes were subtle, they recapitulated relevant changes in diet hormones and cognitive defects [25-28], whereas a similar model for SNORD115 turned out to be less affected [29]. A later mouse study, specifically targeting deletion of SNORD116 to the hypothalamus, produced a more pronounced phenotype, including changes in body weight [30].

Despite the loss of SNORDs being firmly implicated, the mechanism for how this causes PWS and AS remains unclear, particularly since they lack complementarity to rRNAs [19]. Early work on SNORD115 suggested that it may alter splicing of mRNA encoding 5-hydroxytryptamine receptor $2 \mathrm{C}[29,31]$. One of the few molecular studies in the 
SNORD116 knockout mice suggest that they have altered DNA methylation in neuronal genes during the diurnal cycle [32]. Therefore, the emerging picture for these SNORDs is that they are involved in functions quite distinct from the nucleolus. Similar findings are now being reported for orphan snoRNA with relevance to cancers.

Schubert et al. used immunoprecipitation studies to identify specific RNA species that are physically involved in chromatin compaction using drosophila cells. The molecules that were detected included many snoRNA [33]. Falaleeva et al. reported that SNORD27 could operate within a novel complex to compete with U1 snRNA RNPs (snRNPs) in order to alter splicing of mRNA encoding E2F Transcription Factor 7 (E2F7). E2F7 contributes to both head and neck cancers and retinal cancers [34]. Another study found the expression of SNORD88C was similarly altered mRNA splicing for fibroblast growth factor receptor 3 (FGFR3) [35], which contributes to the progression of multiple cancer types [36-38]. Interestingly, this mechanism appeared to involve shorter derived sdRNAs from SNORD88C, and as it turns out, this may be a common way that snoRNA expand their influence. Ender et al. analysed small RNAs associated with immunoprecipitated human AGO1, which forms part of the RISC complex involved in RNA silencing. They found that although the majority of identified species were miRNAs, a fraction were clearly derived from snoRNAs [39]. They went on to show that for each snoRNA represented, SCARNA15 was processed by Dicer and could regulate a reporter gene representing the 3'UTR of cyclin dependent kinase 19 (CDK19) [39]. Moreover, Kawaji et al. performed an unbiased sequencing of human small RNAs and found multiple classes of 20-40 nt species that originated from noncoding RNAs, including snoRNA [12]. This was later confirmed by other studies [13]. More recently, Kalantari et al. demonstrated that RISC complexes can operate both in the nucleus and cytoplasm, which allow sdRNAs to potentially form complexes at either site [40]. Taken together, these various studies show that snoRNA may be engaged in a wide range of molecular mechanisms.

\section{Orphan SNORDs May Be Involved in Regulating Methylation of mRNA}

Importantly, RNA methylation is now also recognised as a frequent modification of cytoplasmic mRNAs in addition to nuclear RNA [41]. In addition, several reports have shown this to be regulatory in nature [42-45] and significant to cancer progression and metastasis [46-50]. An important type of mRNA methylation is adenosine N6methylation (m6A), which is catalysed by the methyltransferase-like proteins 3 and 14 (METTL3/METTL14) [51]. In localisation studies, METTL3 was found in the nucleolus alongside FBL, where it was demonstrated to co-modify rRNA [52]. Another type of mRNA methylation is ribose $2^{\prime}-\mathrm{O}$-methylation $\left(2^{\prime} \mathrm{OMe}\right)$. Elliot et al. used a knockout mouse for SNORD50A to test whether it altered 2'OMe modification of the mRNA for peroxidasin (Pxdn). The methylation was altered and it changed mRNA stability and translation [53]. Therefore, snoRNA may potentially contribute to cancer progression by supporting the methylation of mRNA.

\section{SnoRNAs Are Important Markers of Cancer Establishment, Progression and Metastasis}

Early clues that snoRNA contribute to cancer biology came from several sources. The condition dyskeratosis congenital carries an increased risk of cancers and is caused by mutations in genes involved with snoRNA nucleolus and Cajal body functions, including DKC1 that mediates pseudouridation [54]. SNHG5, a snoRNA host gene that harbours SNORD50, was mapped to the chromosome breakpoint $t(3 ; 6)(\mathrm{q} 27 ; \mathrm{q} 15)$ involved in human B-cell lymphomas [55]. Later, it was also found to be commonly deleted in prostate cancers [56]. Liao et al. used GeneChipR Oligo arrays to show SNORA42 act as an oncogene in non-small cell lung cancers (NSCLC) [57,58]. Similar work showed that SNORD78 also contributed to this disease [59]. Valleron et al. used a RT-qPCR approach to analyse a panel of 80 snoRNA in a subclass of T cell lymphomas. Here, they detected a strong association between SNORD71 and disease outcome [60]. 
As genome-wide expression analysis and RNA-Seq technologies have become more readily available, a number of cancer investigators have used them to assess snoRNA. Schulten et al. analysed gene expression in breast cancer metastases in the brain using microarrays and compared them to non-metastatic breast cancers. In addition to 13 protein coding genes, those differentially expressed included 6 SNORDs, 13 SNORAs and 1 SCARNA, suggesting that the snoRNA supported metastatic progression [61]. Gao et al. analysed 178 non-small cell lung cancers (NSCLC) using a combination of RNA-Seq and RT-qPCR. In total, 458 snoRNA were detected and 29 were elevated compared to normal tissues. In separate training and testing cohorts, they established a prognosis predictor based on three snoRNA: SNORA47, SNORA68 and SNORA78 [62]. Crea et al. performed RNA-Seq on xenografts generated with paired primary and metastases from prostate cancers to identify 21 snoRNA that correlated with metastasis. Here, they highlighted SNORA55 as a probable driver gene [63]. Then, in a landmark pan-cancer analysis, Gong et al. employed bioinformatic mining of small RNA data from the Cancer Genome Atlas (TCGA), representing 31 human cancers. They found approximately 400-500 snoRNA expressed in each cancer type, all of which were generally elevated in expression compared to normal tissues. In total, 203 were associated with the clinical stage and 355 had associations with patient survival, including 229 SNORDs, 108 SNORAs and 18 SCARNAs [64]. Then, focusing on smaller sdRNA sequences, Chow et al. undertook a similar pan-cancer analysis of the TCGA data and found that they too have clear relationships with clinical outcomes across cancers [65]. Previously, Uzunova et al. employed a combination of RNA-Seq and RT-qPCR in a cohort of 106 prostate cancers. They determined that sdRNAs arising from SNORD44, SNORD74, SNORD78 and SNORD81 were upregulated, with SNORD78 associating with metastatic disease [66]. Taken together, these various association studies suggest that snoRNA have significant prognostic value and are well-placed to be contribute to cancer progression and metastasis.

\section{SnoRNA Host Genes May Independently Contribute to Cancer Progression}

Concurrently, there has been a strong interest in the snoRNA host genes themselves and, in short, their expression is generally elevated in cancers and often prognostic [67]. However, it turns out that the snoRNA host gene mRNAs often retain introns and carry snoRNA sequences into the cytoplasm. Therefore, their true mechanisms of action require further clarification. GAS5 was cloned in 1988 from a cDNA library to represent growtharrested NIH/3T3 mouse fibroblasts [68]. Only later was this recognised as a snoRNA host gene [69]. Its expression inhibits the growth of the human T lymphocyte CEM-C7 and MOLT-4 cell lines [70] and similar results have been reported for multiple other cell types [71-75]. ZFAS1, which encodes SNORD12, SNORD12A and SNORD12B, was also cloned early [76] and identified as being expressed in mouse mammary glands and breast cancers [77]. The knockdown of the gene promoted proliferation in breast cancer cells and was silenced in ductal carcinoma in situ (DCIS) [77]. However, subsequent work has shown ZFAS1 to have differing significance in other cancer types such as liver, lung, gastric and colorectal cancers, where it may instead promote tumour growth and metastasis [78-81]. Importantly, multiple studies have suggested that ZFAS1 operates in part as a decoy or "sponge" for miRNA species [78,80]. This concept has emerged as a common theme for the snoRNA host genes as a group [67]. However, it is an open question as to why the expression of snoRNA would be intrinsically linked with the sponging of miRNA. The expression of SNHG1 has been associated with worse outcomes. For example, in multiple cancers, it acts as a miRNA sponge and promotes epithelial-mesenchymal transition (EMT) [82-85]. SNHG3 increased cell progression and sponged miRNAs in osteosarcoma, colorectal and liver cancers [86-88]. SNHG5 promoted proliferation and migration and acted as a miRNA sponge in breast cancers, melanomas, leukaemia and gastric cancers [89-92]. This theme continues with similar findings reported for SNHG6, SNHG7, SNHG12, SNHG15, SNGG16 and SNHG20 [67,93,94]. 
Maternally expressed 8 (MEG8) resides within another imprinted locus DLK1-DIO3, which is responsible for a muscle phenotype in sheep [95] and at least two different conditions in humans [96,97]. MEG8 contains 9 copies of SNORD113 and 31 copies of SNORD114, and thus is comparable to the SNURF-SNURPN locus in nature. Similar to the other host genes, MEG8 promoted EMT in lung and pancreatic cancer cells [98,99], and correlated with poor prognosis in liver cancers [100]. Overall therefore, there is a clear theme that snoRNA host gene expression generally impacts cancer progression and metastasis, perhaps even more so than the snoRNAs linked to their expression.

\section{The Importance of Ribosomes in Cancer Progression and the Role of mTOR Signalling}

When considering how snoRNA may contribute to cancer progression, it is important not to underestimate their canonical role of rRNA modification. Ribosome function is pivotal to cell growth and is upregulated in cancers [101]. The mechanistic target of rapamycin (mTOR) signalling pathway functions to coordinate growth signals from activated Ras and other pathways with ribosome control. The pathway is a principal driver of lymphocyte expansion, and a key oncogenic pathway within cancers [102]. The activation of mTOR leads to an altered constitution of the ribosome, increasing eukaryotic translation initiation factor 4E (eIF4E) inclusion [103], as well as the selective translation of $5^{\prime}$-TOP mRNAs. $5^{\prime}$-TOP mRNAs get their name from an oligopyrimidine tract in their $5^{\prime}$ UTRs that aids their recognition by the ribosome. Further, they encode many of the ribosomal proteins themselves [104,105]. An analysis of snoRNA host genes revealed that these too are usually 5'-TOP mRNAs, so in effect the snoRNAs are controlled by the mTOR pathway [106]. In line with this, GAS5 expression in T lymphocyte cell lines altered their sensitivity to rapamycin [107]. SNORA24 deleted liver cancer cells injected into mice, resulting in tumours that synergised with oncogenic RasG12V and altered ribosome activity [108]. Interestingly, in the clinic, the blockade of mTOR has proved particularly valuable for inhibiting lymphocyte-mediated immune responses (e.g., to prevent organ rejection) and for treating cancers of the kidney. Both of which, may have relevance to to anti-cancer immunity.

\section{The Contribution of snoRNA to Cancer Immunity Has the Potential to Contribute to Disease Progression}

The ability of cancer cells to avoid detection and clearance by the immune system has recently become a central topic in oncology. Cancer cells upregulate expression of proteins (on both themselves and cells of immune system e.g. T lymphocytes) that normally protect non-cancerous cells from cytotoxic immune responses [109]. Antibody-based drugs targeting cytotoxic T-lymphocyte-associated protein 4 (CTLA-4), programmed cell death protein 1 (PD-1) and programmed cell death protein-ligand 1 (PD-L1) have proven superior to existing chemotherapy and radiation approaches for multiple cancer types [109]. In an analysis of acute myeloid leukaemias (AML) and acute lymphoid leukemias (ALL), together with a selection of normal white blood cell lineages, Warner et al. found significant differential expression of snoRNAs, both in the cancers and between the lineages from which they arose. Surprisingly, in addition to 30 SNORDs, 29 SNORAs and 4 SCARNAs from various genomic locations, the detected signatures were dominated by snoRNAs encoded in the SNURF-SNURPN and DLK1-DIO3 loci. Therefore, dysregulation of these imprinted sites appears to be a major feature of blood cancers and these data reiterate that snoRNA are important regulators of lymphocyte activity [110]. Of relevance, Zhong et al. reported that sdRNA derived from SNORD63 may control mRNA stability for lymphocyte regulator interleukin-4 (IL-4) [111]. In the pan-cancer sdRNA analysis conducted by Chow, clear associations were detected with PD-L1 expression for multiple cancer types and particularly for cancers of the kidney [65]. Finally, Motzer et al. recently defined molecular subtypes for kidney cancers (using all genes) and included measures of their response to anti-PD-L1 therapy. The 823 included cancers were grouped into seven subsets by non-hierarchal clustering. One of these was defined by marked snoRNA expression; this group was by far the most responsive to anti-PD-L1 [112]. Taken together, these findings 
suggest that snoRNA expression is of high relevance to lymphocyte function and the immune response against cancers, as well as the oncogenic mechanisms that promote their progression to metastatic disease (Figure 2).

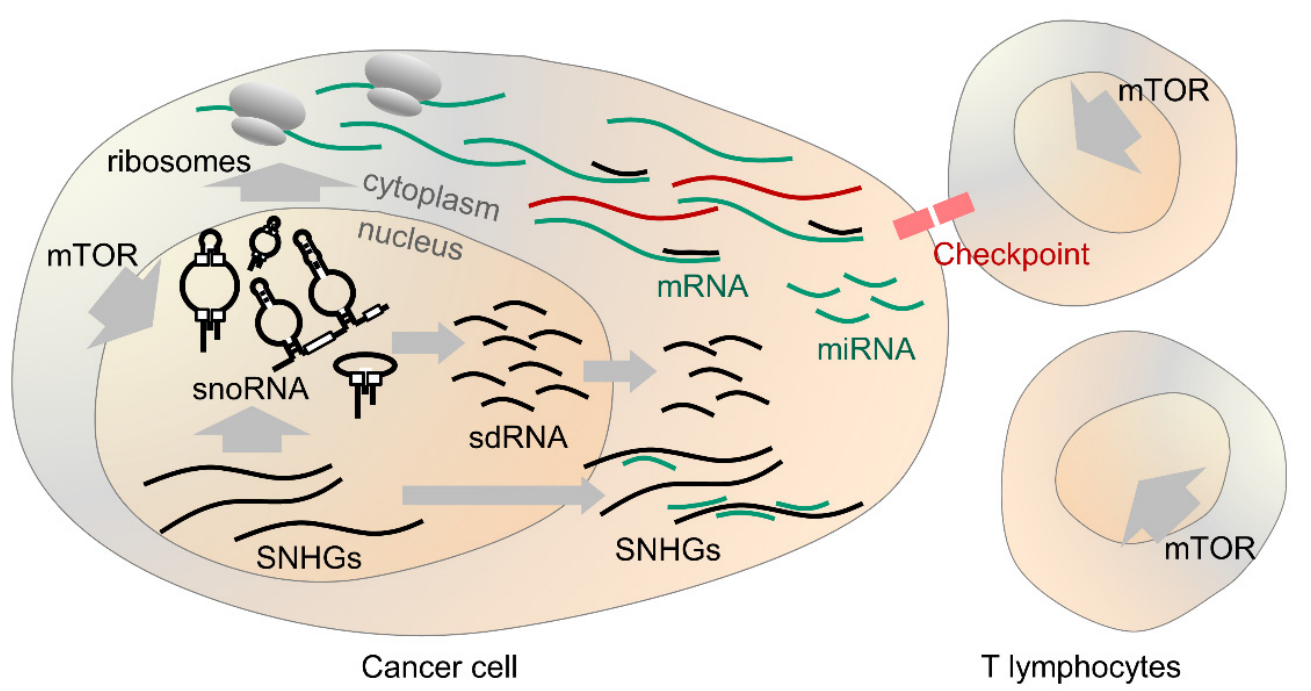

Figure 2. Overview of snoRNA in cancer. SnoRNA expression is promoted by mTOR both in cancer cells and T lymphocytes acting against them. SnoRNA facilitate the production of ribosomes and protein translation. SNHGs produce snoRNA and sponge miRNA in the cytoplasm. SnoRNA derived species may alter splicing and function of mRNAs. In some cases, snoRNA correlate with response to therapeutic targeting of the immune checkpoint proteins.

\section{SnoRNA Present Novel Therapeutic Opportunities to Combat Cancer Progression and Metastasis}

Finally, given the emerging data that snoRNA are modifiers of cancer progression and metastasis, can they be therapeutically targeted? Several new technologies now provide significant hope [113]. Adenovirus-mediated delivery of SNORD44 from the growth inhibitory GAS5 gene inhibited CRC growth and synergised with rapamycin treatment in CRC cell line xenografts [114]. Antisense oligonucleotide (ASO)-mediated downregulation of SNORA23 reduced tumour growth, dissemination and liver metastasis in pancreatic ductal adenocarcinoma xenografts [115]. Therefore, snoRNA may have value both as drug targets in cancers or as therapeutics themselves.

\section{Conclusions}

Although snoRNA cancer research had a slow start, revelations from genome and transcriptome sequencing has now firmly illuminated their relevance to cancer biology. The extraordinarily large number of snoRNAs expressed in our cells, as well as the mounting evidence that they can alter cancer progression and patient survival, suggests that they have solid potential for therapeutic manipulation. Their control by mTOR and importance to ribosome function is a key aspect of their contribution, but their unknown functions are likely to be important also. Moreover, their specific contribution to lymphocyte function means that they may have relevance to a patient's immunotherapy response. Emerging technologies that allow for their therapeutic manipulation makes them an important consideration for combating cancer progression and metastasis.

Author Contributions: Writing—original draft preparation, J.v.d.W.; writing—review and editing, N.I.F. and C.V.C.; supervision, N.I.F. All authors have read and agreed to the published version of the manuscript.

Funding: N.I.F. was supported by a New Zealand Health Research Council (HRC) Career Development Award (CDA). 
Informed Consent Statement: Not applicable.

Data Availability Statement: Not applicable.

Conflicts of Interest: The authors declare no conflict of interest.

\section{References}

1. Bouchard-Bourelle, P.; Desjardins-Henri, C.; Mathurin-St-Pierre, D.; Deschamps-Francoeur, G.; Fafard-Couture, E.; Garant, J.M.; Elela, S.A.; Scott, M.S. snoDB: An interactive database of human snoRNA sequences, abundance and interactions. Nucleic Acids Res. 2020, 48, D220-D225. [CrossRef]

2. Busch, H.; Reddy, R.; Rothblum, L.; Choi, Y.C. SnRNAs, SnRNPs, and RNA processing. Annu. Rev. Biochem. 1982, 51, 617-654. [CrossRef] [PubMed]

3. Weinberg, R.A.; Penman, S. Small molecular weight monodisperse nuclear RNA. J. Mol. Biol. 1968, 38, 289-304. [CrossRef]

4. Gurney, T., Jr.; Eliceiri, G.L. Intracellular distribution of low molecular weight RNA species in HeLa cells. J. Cell Biol. 1980, 87, 398-403. [CrossRef] [PubMed]

5. Balakin, A.G.; Smith, L.; Fournier, M.J. The RNA world of the nucleolus: Two major families of small RNAs defined by different box elements with related functions. Cell 1996, 86, 823-834. [CrossRef]

6. Dupuis-Sandoval, F.; Poirier, M.; Scott, M.S. The emerging landscape of small nucleolar RNAs in cell biology. Wiley Interdiscip. Rev. RNA 2015, 6, 381-397. [CrossRef] [PubMed]

7. Jorjani, H.; Kehr, S.; Jedlinski, D.J.; Gumienny, R.; Hertel, J.; Stadler, P.F.; Zavolan, M.; Gruber, A.R. An updated human snoRNAome. Nucleic Acids Res. 2016, 44, 5068-5082. [CrossRef] [PubMed]

8. Yin, Q.F.; Yang, L.; Zhang, Y.; Xiang, J.F.; Wu, Y.W.; Carmichael, G.G.; Chen, L.L. Long noncoding RNAs with snoRNA ends. Mol. Cell 2012, 48, 219-230. [CrossRef] [PubMed]

9. Zhang, X.O.; Yin, Q.F.; Wang, H.B.; Zhang, Y.; Chen, T.; Zheng, P.; Lu, X.; Chen, L.L.; Yang, L. Species-specific alternative splicing leads to unique expression of sno-lncRNAs. BMC Genom. 2014, 15, 287. [CrossRef]

10. Wu, H.; Yin, Q.F.; Luo, Z.; Yao, R.W.; Zheng, C.C.; Zhang, J.; Xiang, J.F.; Yang, L.; Chen, L.L. Unusual Processing Generates SPA LncRNAs that Sequester Multiple RNA Binding Proteins. Mol. Cell 2016, 64, 534-548. [CrossRef]

11. Kishore, S.; Gruber, A.R.; Jedlinski, D.J.; Syed, A.P.; Jorjani, H.; Zavolan, M. Insights into snoRNA biogenesis and processing from PAR-CLIP of snoRNA core proteins and small RNA sequencing. Genome Biol. 2013, 14, R45. [CrossRef]

12. Kawaji, H.; Nakamura, M.; Takahashi, Y.; Sandelin, A.; Katayama, S.; Fukuda, S.; Daub, C.O.; Kai, C.; Kawai, J.; Yasuda, J.; et al. Hidden layers of human small RNAs. BMC Genom. 2008, 9, 157. [CrossRef]

13. Taft, R.J.; Glazov, E.A.; Lassmann, T.; Hayashizaki, Y.; Carninci, P.; Mattick, J.S. Small RNAs derived from snoRNAs. RNA 2009, 15, 1233-1240. [CrossRef] [PubMed]

14. Kiss-Laszlo, Z.; Henry, Y.; Kiss, T. Sequence and structural elements of methylation guide snoRNAs essential for site-specific ribose methylation of pre-rRNA. EMBO J. 1998, 17, 797-807. [CrossRef] [PubMed]

15. Henras, A.K.; Dez, C.; Henry, Y. RNA structure and function in C/D and H/ACA s(no)RNPs. Curr. Opin. Struct. Biol. 2004, 14, 335-343. [CrossRef] [PubMed]

16. Ganot, P.; Bortolin, M.L.; Kiss, T. Site-specific pseudouridine formation in preribosomal RNA is guided by small nucleolar RNAs. Cell 1997, 89, 799-809. [CrossRef]

17. Kiss, T. Small nucleolar RNA-guided post-transcriptional modification of cellular RNAs. EMBO J. 2001, 20, 3617-3622. [CrossRef] [PubMed]

18. Angulo, M.A.; Butler, M.G.; Cataletto, M.E. Prader-Willi syndrome: A review of clinical, genetic, and endocrine findings. J. Endocrinol. Invest. 2015, 38, 1249-1263. [CrossRef]

19. Cavaille, J.; Buiting, K.; Kiefmann, M.; Lalande, M.; Brannan, C.I.; Horsthemke, B.; Bachellerie, J.P.; Brosius, J.; Huttenhofer, A. Identification of brain-specific and imprinted small nucleolar RNA genes exhibiting an unusual genomic organization. Proc. Natl. Acad. Sci. USA 2000, 97, 14311-14316. [CrossRef]

20. Kishore, S.; Stamm, S. The snoRNA HBII-52 regulates alternative splicing of the serotonin receptor 2C. Science 2006, 311, $230-232$. [CrossRef]

21. Vitali, P.; Basyuk, E.; Le Meur, E.; Bertrand, E.; Muscatelli, F.; Cavaille, J.; Huttenhofer, A. ADAR2-mediated editing of RNA substrates in the nucleolus is inhibited by C/D small nucleolar RNAs. J. Cell Biol. 2005, 169, 745-753. [CrossRef] [PubMed]

22. Sahoo, T.; del Gaudio, D.; German, J.R.; Shinawi, M.; Peters, S.U.; Person, R.E.; Garnica, A.; Cheung, S.W.; Beaudet, A.L. Prader-Willi phenotype caused by paternal deficiency for the HBII-85 C/D box small nucleolar RNA cluster. Nat. Genet. 2008, 40, 719-721. [CrossRef] [PubMed]

23. Duker, A.L.; Ballif, B.C.; Bawle, E.V.; Person, R.E.; Mahadevan, S.; Alliman, S.; Thompson, R.; Traylor, R.; Bejjani, B.A.; Shaffer, L.G.; et al. Paternally inherited microdeletion at 15q11.2 confirms a significant role for the SNORD116 C/D box snoRNA cluster in Prader-Willi syndrome. Eur. J. Hum. Genet. 2010, 18, 1196-1201. [CrossRef] [PubMed]

24. de Smith, A.J.; Purmann, C.; Walters, R.G.; Ellis, R.J.; Holder, S.E.; Van Haelst, M.M.; Brady, A.F.; Fairbrother, U.L.; Dattani, M.; Keogh, J.M.; et al. A deletion of the HBII-85 class of small nucleolar RNAs (snoRNAs) is associated with hyperphagia, obesity and hypogonadism. Hum. Mol. Genet. 2009, 18, 3257-3265. [CrossRef] 
25. Ding, F.; Li, H.H.; Zhang, S.; Solomon, N.M.; Camper, S.A.; Cohen, P.; Francke, U. SnoRNA Snord116 (Pwcr1/MBII-85) deletion causes growth deficiency and hyperphagia in mice. PLoS ONE 2008, 3, e1709. [CrossRef]

26. Adhikari, A.; Copping, N.A.; Onaga, B.; Pride, M.C.; Coulson, R.L.; Yang, M.; Yasui, D.H.; LaSalle, J.M.; Silverman, J.L. Cognitive deficits in the Snord116 deletion mouse model for Prader-Willi syndrome. Neurobiol. Learn. Mem. 2019, 165, 106874. [CrossRef]

27. Qi, Y.; Purtell, L.; Fu, M.; Lee, N.J.; Aepler, J.; Zhang, L.; Loh, K.; Enriquez, R.F.; Baldock, P.A.; Zolotukhin, S.; et al. Snord116 is critical in the regulation of food intake and body weight. Sci. Rep. 2016, 6, 18614. [CrossRef] [PubMed]

28. Skryabin, B.V.; Gubar, L.V.; Seeger, B.; Pfeiffer, J.; Handel, S.; Robeck, T.; Karpova, E.; Rozhdestvensky, T.S.; Brosius, J. Deletion of the MBII-85 snoRNA gene cluster in mice results in postnatal growth retardation. PLoS Genet. 2007, 3, e235. [CrossRef]

29. Hebras, J.; Marty, V.; Personnaz, J.; Mercier, P.; Krogh, N.; Nielsen, H.; Aguirrebengoa, M.; Seitz, H.; Pradere, J.P.; Guiard, B.P.; et al. Reassessment of the involvement of Snord115 in the serotonin 2c receptor pathway in a genetically relevant mouse model. eLife 2020, 9. [CrossRef]

30. Polex-Wolf, J.; Lam, B.Y.; Larder, R.; Tadross, J.; Rimmington, D.; Bosch, F.; Cenzano, V.J.; Ayuso, E.; Ma, M.K.; Rainbow, K.; et al. Hypothalamic loss of Snord116 recapitulates the hyperphagia of Prader-Willi syndrome. J. Clin. Investig. 2018, 128, 960-969. [CrossRef] [PubMed]

31. Garfield, A.S.; Davies, J.R.; Burke, L.K.; Furby, H.V.; Wilkinson, L.S.; Heisler, L.K.; Isles, A.R. Increased alternate splicing of Htr2c in a mouse model for Prader-Willi syndrome leads disruption of 5HT2C receptor mediated appetite. Mol. Brain 2016,9 , 95. [CrossRef]

32. Coulson, R.L.; Yasui, D.H.; Dunaway, K.W.; Laufer, B.I.; Vogel Ciernia, A.; Zhu, Y.; Mordaunt, C.E.; Totah, T.S.; LaSalle, J.M. Snord116-dependent diurnal rhythm of DNA methylation in mouse cortex. Nat. Commun. 2018, 9, 1616. [CrossRef]

33. Schubert, T.; Pusch, M.C.; Diermeier, S.; Benes, V.; Kremmer, E.; Imhof, A.; Langst, G. Df31 protein and snoRNAs maintain accessible higher-order structures of chromatin. Mol. Cell 2012, 48, 434-444. [CrossRef] [PubMed]

34. Falaleeva, M.; Pages, A.; Matuszek, Z.; Hidmi, S.; Agranat-Tamir, L.; Korotkov, K.; Nevo, Y.; Eyras, E.; Sperling, R.; Stamm, S. Dual function of C/D box small nucleolar RNAs in rRNA modification and alternative pre-mRNA splicing. Proc. Natl. Acad. Sci. USA 2016, 113, E1625-E1634. [CrossRef]

35. Scott, M.S.; Ono, M.; Yamada, K.; Endo, A.; Barton, G.J.; Lamond, A.I. Human box C/D snoRNA processing conservation across multiple cell types. Nucleic Acids Res. 2012, 40, 3676-3688. [CrossRef]

36. Chew, N.J.; Nguyen, E.V.; Su, S.P.; Novy, K.; Chan, H.C.; Nguyen, L.K.; Luu, J.; Simpson, K.J.; Lee, R.S.; Daly, R.J. FGFR3 signaling and function in triple negative breast cancer. Cell Commun. Signal. 2020, 18, 13. [CrossRef] [PubMed]

37. Kacew, A.; Sweis, R.F. FGFR3 Alterations in the Era of Immunotherapy for Urothelial Bladder Cancer. Front. Immunol. 2020, 11, 575258. [CrossRef] [PubMed]

38. Fromme, J.E.; Schildhaus, H.U. FGFR3 overexpression is a relevant alteration in colorectal cancer. Pathologe 2018, 39, 189-192. [CrossRef] [PubMed]

39. Ender, C.; Krek, A.; Friedlander, M.R.; Beitzinger, M.; Weinmann, L.; Chen, W.; Pfeffer, S.; Rajewsky, N.; Meister, G. A human snoRNA with microRNA-like functions. Mol. Cell 2008, 32, 519-528. [CrossRef]

40. Kalantari, R.; Hicks, J.A.; Li, L.; Gagnon, K.T.; Sridhara, V.; Lemoff, A.; Mirzaei, H.; Corey, D.R. Stable association of RNAi machinery is conserved between the cytoplasm and nucleus of human cells. RNA 2016, 22, 1085-1098. [CrossRef]

41. Barbieri, I.; Kouzarides, T. Role of RNA modifications in cancer. Nat. Rev. Cancer 2020, 20, 303-322. [CrossRef] [PubMed]

42. Meyer, K.D.; Patil, D.P.; Zhou, J.; Zinoviev, A.; Skabkin, M.A.; Elemento, O.; Pestova, T.V.; Qian, S.B.; Jaffrey, S.R. 5' UTR m(6)A Promotes Cap-Independent Translation. Cell 2015, 163, 999-1010. [CrossRef]

43. Wang, X.; Lu, Z.; Gomez, A.; Hon, G.C.; Yue, Y.; Han, D.; Fu, Y.; Parisien, M.; Dai, Q.; Jia, G.; et al. N6-methyladenosine-dependent regulation of messenger RNA stability. Nature 2014, 505, 117-120. [CrossRef]

44. Bertero, A.; Brown, S.; Madrigal, P.; Osnato, A.; Ortmann, D.; Yiangou, L.; Kadiwala, J.; Hubner, N.C.; de Los Mozos, I.R.; Sadee, C.; et al. The SMAD2/3 interactome reveals that TGFbeta controls m(6)A mRNA methylation in pluripotency. Nature 2018, 555, 256-259. [CrossRef] [PubMed]

45. Ayadi, L.; Galvanin, A.; Pichot, F.; Marchand, V.; Motorin, Y. RNA ribose methylation (2'-O-methylation): Occurrence, biosynthesis and biological functions. Biochim. Biophys. Acta Gene Regul. Mech. 2019, 1862, 253-269. [CrossRef]

46. Zhang, C.; Zhang, M.; Ge, S.; Huang, W.; Lin, X.; Gao, J.; Gong, J.; Shen, L. Reduced m6A modification predicts malignant phenotypes and augmented Wnt/PI3K-Akt signaling in gastric cancer. Cancer Med. 2019, 8, 4766-4781. [CrossRef]

47. Zhang, C.; Huang, S.; Zhuang, H.; Ruan, S.; Zhou, Z.; Huang, K.; Ji, F.; Ma, Z.; Hou, B.; He, X. YTHDF2 promotes the liver cancer stem cell phenotype and cancer metastasis by regulating OCT4 expression via m6A RNA methylation. Oncogene 2020, 39, 4507-4518. [CrossRef]

48. Guan, K.; Liu, X.; Li, J.; Ding, Y.; Li, J.; Cui, G.; Cui, X.; Sun, R. Expression Status And Prognostic Value Of M6A-associated Genes in Gastric Cancer. J. Cancer 2020, 11, 3027-3040. [CrossRef] [PubMed]

49. Ji, G.; Huang, C.; He, S.; Gong, Y.; Song, G.; Li, X.; Zhou, L. Comprehensive analysis of m6A regulators prognostic value in prostate cancer. Aging (Albany NY) 2020, 12, 14863-14884. [CrossRef]

50. Song, P.; Tayier, S.; Cai, Z.; Jia, G. RNA methylation in mammalian development and cancer. Cell Biol. Toxicol. 2021. [CrossRef] [PubMed] 
51. Dominissini, D.; Moshitch-Moshkovitz, S.; Schwartz, S.; Salmon-Divon, M.; Ungar, L.; Osenberg, S.; Cesarkas, K.; Jacob-Hirsch, J.; Amariglio, N.; Kupiec, M.; et al. Topology of the human and mouse m6A RNA methylomes revealed by m6A-seq. Nature 2012, 485, 201-206. [CrossRef]

52. Sergeeva, O.; Sergeev, P.; Melnikov, P.; Prikazchikova, T.; Dontsova, O.; Zatsepin, T. Modification of Adenosine196 by Mettl3 Methyltransferase in the 5'-External Transcribed Spacer of 47S Pre-rRNA Affects rRNA Maturation. Cells 2020, 9, 1061. [CrossRef] [PubMed]

53. Elliott, B.A.; Ho, H.T.; Ranganathan, S.V.; Vangaveti, S.; Ilkayeva, O.; Abou Assi, H.; Choi, A.K.; Agris, P.F.; Holley, C.L. Modification of messenger RNA by 2'-O-methylation regulates gene expression in vivo. Nat. Commun. 2019, 10, 3401. [CrossRef] [PubMed]

54. Heiss, N.S.; Knight, S.W.; Vulliamy, T.J.; Klauck, S.M.; Wiemann, S.; Mason, P.J.; Poustka, A.; Dokal, I. X-linked dyskeratosis congenita is caused by mutations in a highly conserved gene with putative nucleolar functions. Nat. Genet. 1998, 19, 32-38. [CrossRef] [PubMed]

55. Tanaka, R.; Satoh, H.; Moriyama, M.; Satoh, K.; Morishita, Y.; Yoshida, S.; Watanabe, T.; Nakamura, Y.; Mori, S. Intronic U50 small-nucleolar-RNA (snoRNA) host gene of no protein-coding potential is mapped at the chromosome breakpoint $t(3 ; 6)(q 27 ; q 15)$ of human B-cell lymphoma. Genes. Cells 2000, 5, 277-287. [CrossRef]

56. Dong, X.Y.; Rodriguez, C.; Guo, P.; Sun, X.; Talbot, J.T.; Zhou, W.; Petros, J.; Li, Q.; Vessella, R.L.; Kibel, A.S.; et al. SnoRNA U50 is a candidate tumor-suppressor gene at $6 \mathrm{q} 14.3$ with a mutation associated with clinically significant prostate cancer. Hum. Mol. Genet. 2008, 17, 1031-1042. [CrossRef]

57. Liao, J.; Yu, L.; Mei, Y.; Guarnera, M.; Shen, J.; Li, R.; Liu, Z.; Jiang, F. Small nucleolar RNA signatures as biomarkers for non-small-cell lung cancer. Mol. Cancer 2010, 9, 198. [CrossRef]

58. Mei, Y.P.; Liao, J.P.; Shen, J.; Yu, L.; Liu, B.L.; Liu, L.; Li, R.Y.; Ji, L.; Dorsey, S.G.; Jiang, Z.R.; et al. Small nucleolar RNA 42 acts as an oncogene in lung tumorigenesis. Oncogene 2012, 31, 2794-2804. [CrossRef]

59. Zheng, D.; Zhang, J.; Ni, J.; Luo, J.; Wang, J.; Tang, L.; Zhang, L.; Wang, L.; Xu, J.; Su, B.; et al. Small nucleolar RNA 78 promotes the tumorigenesis in non-small cell lung cancer. J. Exp. Clin. Cancer Res. 2015, 34, 49. [CrossRef]

60. Valleron, W.; Ysebaert, L.; Berquet, L.; Fataccioli, V.; Quelen, C.; Martin, A.; Parrens, M.; Lamant, L.; de Leval, L.; Gisselbrecht, C.; et al. Small nucleolar RNA expression profiling identifies potential prognostic markers in peripheral T-cell lymphoma. Blood 2012, 120, 3997-4005. [CrossRef]

61. Schulten, H.J.; Bangash, M.; Karim, S.; Dallol, A.; Hussein, D.; Merdad, A.; Al-Thoubaity, F.K.; Al-Maghrabi, J.; Jamal, A.; Al-Ghamdi, F.; et al. Comprehensive molecular biomarker identification in breast cancer brain metastases. J. Transl. Med. 2017, 15, 269. [CrossRef]

62. Gao, L.; Ma, J.; Mannoor, K.; Guarnera, M.A.; Shetty, A.; Zhan, M.; Xing, L.; Stass, S.A.; Jiang, F. Genome-wide small nucleolar RNA expression analysis of lung cancer by next-generation deep sequencing. Int. J. Cancer. 2015, 136, E623-E629. [CrossRef] [PubMed]

63. Crea, F.; Quagliata, L.; Michael, A.; Liu, H.H.; Frumento, P.; Azad, A.A.; Xue, H.; Pikor, L.; Watahiki, A.; Morant, R.; et al. Integrated analysis of the prostate cancer small-nucleolar transcriptome reveals SNORA55 as a driver of prostate cancer progression. Mol. Oncol. 2016, 10, 693-703. [CrossRef] [PubMed]

64. Gong, J.; Li, Y.; Liu, C.J.; Xiang, Y.; Li, C.; Ye, Y.; Zhang, Z.; Hawke, D.H.; Park, P.K.; Diao, L.; et al. A Pan-cancer Analysis of the Expression and Clinical Relevance of Small Nucleolar RNAs in Human Cancer. Cell Rep. 2017, 21, 1968-1981. [CrossRef] [PubMed]

65. Chow, R.D.; Chen, S. Sno-derived RNAs are prevalent molecular markers of cancer immunity. Oncogene 2018, $37,6442-6462$. [CrossRef]

66. Martens-Uzunova, E.S.; Hoogstrate, Y.; Kalsbeek, A.; Pigmans, B.; Vredenbregt-van den Berg, M.; Dits, N.; Nielsen, S.J.; Baker, A.; Visakorpi, T.; Bangma, C.; et al. C/D-box snoRNA-derived RNA production is associated with malignant transformation and metastatic progression in prostate cancer. Oncotarget 2015, 6, 17430-17444. [CrossRef]

67. Zimta, A.A.; Tigu, A.B.; Braicu, C.; Stefan, C.; Ionescu, C.; Berindan-Neagoe, I. An Emerging Class of Long Non-coding RNA with Oncogenic Role Arises From the snoRNA Host Genes. Front. Oncol. 2020, 10, 389. [CrossRef]

68. Schneider, C.; King, R.M.; Philipson, L. Genes specifically expressed at growth arrest of mammalian cells. Cell 1988, 54, 787-793. [CrossRef]

69. Smith, C.M.; Steitz, J.A. Classification of gas5 as a multi-small-nucleolar-RNA (snoRNA) host gene and a member of the 5'terminal oligopyrimidine gene family reveals common features of snoRNA host genes. Mol. Cell. Biol. 1998, 18, 6897-6909. [CrossRef]

70. Mourtada-Maarabouni, M.; Hedge, V.L.; Kirkham, L.; Farzaneh, F.; Williams, G.T. Growth arrest in human T-cells is controlled by the non-coding RNA growth-arrest-specific transcript 5 (GAS5). J. Cell Sci. 2008, 121, 939-946. [CrossRef]

71. Qiao, H.P.; Gao, W.S.; Huo, J.X.; Yang, Z.S. Long non-coding RNA GAS5 functions as a tumor suppressor in renal cell carcinoma. Asian Pac. J. Cancer Prev. 2013, 14, 1077-1082. [CrossRef] [PubMed]

72. Mourtada-Maarabouni, M.; Pickard, M.R.; Hedge, V.L.; Farzaneh, F.; Williams, G.T. GAS5, a non-protein-coding RNA, controls apoptosis and is downregulated in breast cancer. Oncogene 2009, 28, 195-208. [CrossRef] [PubMed]

73. Pickard, M.R.; Mourtada-Maarabouni, M.; Williams, G.T. Long non-coding RNA GAS5 regulates apoptosis in prostate cancer cell lines. Biochim. Biophys. Acta 2013, 1832, 1613-1623. [CrossRef] [PubMed] 
74. Lu, X.; Fang, Y.; Wang, Z.; Xie, J.; Zhan, Q.; Deng, X.; Chen, H.; Jin, J.; Peng, C.; Li, H.; et al. Downregulation of gas5 increases pancreatic cancer cell proliferation by regulating CDK6. Cell Tissue Res. 2013, 354, 891-896. [CrossRef]

75. Liu, Z.; Wang, W.; Jiang, J.; Bao, E.; Xu, D.; Zeng, Y.; Tao, L.; Qiu, J. Downregulation of GAS5 promotes bladder cancer cell proliferation, partly by regulating CDK6. PLoS ONE 2013, 8, e73991. [CrossRef] [PubMed]

76. Carninci, P.; Shibata, Y.; Hayatsu, N.; Sugahara, Y.; Shibata, K.; Itoh, M.; Konno, H.; Okazaki, Y.; Muramatsu, M.; Hayashizaki, Y. Normalization and subtraction of cap-trapper-selected cDNAs to prepare full-length cDNA libraries for rapid discovery of new genes. Genome Res. 2000, 10, 1617-1630. [CrossRef] [PubMed]

77. Askarian-Amiri, M.E.; Crawford, J.; French, J.D.; Smart, C.E.; Smith, M.A.; Clark, M.B.; Ru, K.; Mercer, T.R.; Thompson, E.R.; Lakhani, S.R.; et al. SNORD-host RNA Zfas1 is a regulator of mammary development and a potential marker for breast cancer. RNA 2011, 17, 878-891. [CrossRef] [PubMed]

78. Li, T.; Xie, J.; Shen, C.; Cheng, D.; Shi, Y.; Wu, Z.; Deng, X.; Chen, H.; Shen, B.; Peng, C.; et al. Amplification of Long Noncoding RNA ZFAS1 Promotes Metastasis in Hepatocellular Carcinoma. Cancer Res. 2015, 75, 3181-3191. [CrossRef]

79. Nie, F.; Yu, X.; Huang, M.; Wang, Y.; Xie, M.; Ma, H.; Wang, Z.; De, W.; Sun, M. Long noncoding RNA ZFAS1 promotes gastric cancer cells proliferation by epigenetically repressing KLF2 and NKD2 expression. Oncotarget 2017, 8, 38227-38238. [CrossRef] [PubMed]

80. Thorenoor, N.; Faltejskova-Vychytilova, P.; Hombach, S.; Mlcochova, J.; Kretz, M.; Svoboda, M.; Slaby, O. Long non-coding RNA ZFAS1 interacts with CDK1 and is involved in p53-dependent cell cycle control and apoptosis in colorectal cancer. Oncotarget 2016, 7, 622-637. [CrossRef]

81. Tian, F.M.; Meng, F.Q.; Wang, X.B. Overexpression of long-noncoding RNA ZFAS1 decreases survival in human NSCLC patients. Eur. Rev. Med. Pharmacol. Sci. 2016, 20, 5126-5131.

82. Tian, T.; Qiu, R.; Qiu, X. SNHG1 promotes cell proliferation by acting as a sponge of miR-145 in colorectal cancer. Oncotarget 2018, 9, 2128-2139. [CrossRef] [PubMed]

83. Li, J.; Zhang, Z.; Xiong, L.; Guo, C.; Jiang, T.; Zeng, L.; Li, G.; Wang, J. SNHG1 lncRNA negatively regulates miR-199a-3p to enhance CDK7 expression and promote cell proliferation in prostate cancer. Biochem. Biophys. Res. Commun. 2017, 487, 146-152. [CrossRef]

84. Zhang, Y.; Jin, X.; Wang, Z.; Zhang, X.; Liu, S.; Liu, G. Downregulation of SNHG1 suppresses cell proliferation and invasion by regulating Notch signaling pathway in esophageal squamous cell cancer. Cancer Biomark. 2017, 21, 89-96. [CrossRef] [PubMed]

85. Lu, Q.; Shan, S.; Li, Y.; Zhu, D.; Jin, W.; Ren, T. Long noncoding RNA SNHG1 promotes non-small cell lung cancer progression by up-regulating MTDH via sponging miR-145-5p. FASEB J. 2018, 32, 3957-3967. [CrossRef]

86. Zheng, S.; Jiang, F.; Ge, D.; Tang, J.; Chen, H.; Yang, J.; Yao, Y.; Yan, J.; Qiu, J.; Yin, Z.; et al. LncRNA SNHG3/miRNA-151a3p/RAB22A axis regulates invasion and migration of osteosarcoma. Biomed. Pharmacother. 2019, 112, 108695. [CrossRef]

87. Huang, W.; Tian, Y.; Dong, S.; Cha, Y.; Li, J.; Guo, X.; Yuan, X. The long non-coding RNA SNHG3 functions as a competing endogenous RNA to promote malignant development of colorectal cancer. Oncol. Rep. 2017, 38, 1402-1410. [CrossRef]

88. Zhang, T.; Cao, C.; Wu, D.; Liu, L. SNHG3 correlates with malignant status and poor prognosis in hepatocellular carcinoma. Tumour Biol. 2016, 37, 2379-2385. [CrossRef] [PubMed]

89. Chi, J.R.; Yu, Z.H.; Liu, B.W.; Zhang, D.; Ge, J.; Yu, Y.; Cao, X.C. SNHG5 Promotes Breast Cancer Proliferation by Sponging the miR-154-5p/PCNA Axis. Mol. Ther. Nucleic Acids 2019, 17, 138-149. [CrossRef] [PubMed]

90. He, B.; Bai, Y.; Kang, W.; Zhang, X.; Jiang, X. LncRNA SNHG5 regulates imatinib resistance in chronic myeloid leukemia via acting as a CeRNA against MiR-205-5p. Am. J. Cancer Res. 2017, 7, 1704-1713.

91. Gao, J.; Zeng, K.; Liu, Y.; Gao, L.; Liu, L. LncRNA SNHG5 promotes growth and invasion in melanoma by regulating the miR-26a-5p/TRPC3 pathway. Onco. Targets Ther. 2019, 12, 169-179. [CrossRef]

92. Zhao, L.; Han, T.; Li, Y.; Sun, J.; Zhang, S.; Liu, Y.; Shan, B.; Zheng, D.; Shi, J. The lncRNA SNHG5/miR-32 axis regulates gastric cancer cell proliferation and migration by targeting KLF4. FASEB J. 2017, 31, 893-903. [CrossRef]

93. Gong, C.Y.; Tang, R.; Nan, W.; Zhou, K.S.; Zhang, H.H. Role of SNHG16 in human cancer. Clin. Chim. Acta 2020, 503, 175-180. [CrossRef]

94. Tamang, S.; Acharya, V.; Roy, D.; Sharma, R.; Aryaa, A.; Sharma, U.; Khandelwal, A.; Prakash, H.; Vasquez, K.M.; Jain, A. SNHG12: An LncRNA as a Potential Therapeutic Target and Biomarker for Human Cancer. Front. Oncol. 2019, 9, 901. [CrossRef]

95. Charlier, C.; Segers, K.; Wagenaar, D.; Karim, L.; Berghmans, S.; Jaillon, O.; Shay, T.; Weissenbach, J.; Cockett, N.; Gyapay, G.; et al. Human-ovine comparative sequencing of a 250-kb imprinted domain encompassing the callipyge (clpg) locus and identification of six imprinted transcripts: DLK1, DAT, GTL2, PEG11, antiPEG11, and MEG8. Genome Res. 2001, 11, 850-862. [CrossRef] [PubMed]

96. Ogata, T.; Kagami, M. Kagami-Ogata syndrome: A clinically recognizable upd(14)pat and related disorder affecting the chromosome 14q32.2 imprinted region. J. Hum. Genet. 2016, 61, 87-94. [CrossRef] [PubMed]

97. Kagami, M.; Nagasaki, K.; Kosaki, R.; Horikawa, R.; Naiki, Y.; Saitoh, S.; Tajima, T.; Yorifuji, T.; Numakura, C.; Mizuno, S.; et al. Temple syndrome: Comprehensive molecular and clinical findings in 32 Japanese patients. Genet. Med. 2017, 19, 1356-1366. [CrossRef] [PubMed]

98. Terashima, M.; Ishimura, A.; Wanna-Udom, S.; Suzuki, T. MEG8 long noncoding RNA contributes to epigenetic progression of the epithelial-mesenchymal transition of lung and pancreatic cancer cells. J. Biol. Chem. 2018, 293, 18016-18030. [CrossRef] [PubMed] 
99. Liu, Y.; Li, L.; Shang, P.; Song, X. LncRNA MEG8 promotes tumor progression of non-small cell lung cancer via regulating miR-107/CDK6 axis. Anticancer Drugs 2020, 31, 1065-1073. [CrossRef]

100. Lou, J.; Yan, W.; Li, Q.Y.; Zhu, A.K.; Tan, B.Q.; Dong, R.; Zou, X.Z.; Liu, T. LncRNA MEG8 plays an oncogenic role in hepatocellular carcinoma progression through miR-367-3p/14-3-3zeta/TGFbetaR1 axis. Neoplasma 2021, 68, 273-282. [CrossRef]

101. Pelletier, J.; Thomas, G.; Volarevic, S. Ribosome biogenesis in cancer: New players and therapeutic avenues. Nat. Rev. Cancer 2018, 18, 51-63. [CrossRef]

102. Seeliger, H.; Guba, M.; Kleespies, A.; Jauch, K.W.; Bruns, C.J. Role of mTOR in solid tumor systems: A therapeutical target against primary tumor growth, metastases, and angiogenesis. Cancer Metastasis Rev. 2007, 26, 611-621. [CrossRef] [PubMed]

103. Pause, A.; Belsham, G.J.; Gingras, A.C.; Donze, O.; Lin, T.A.; Lawrence, J.C., Jr.; Sonenberg, N. Insulin-dependent stimulation of protein synthesis by phosphorylation of a regulator of 5'-cap function. Nature 1994, 371, 762-767. [CrossRef] [PubMed]

104. Perry, R.P. The architecture of mammalian ribosomal protein promoters. BMC Evol. Biol. 2005, 5, 15. [CrossRef] [PubMed]

105. Tcherkezian, J.; Cargnello, M.; Romeo, Y.; Huttlin, E.L.; Lavoie, G.; Gygi, S.P.; Roux, P.P. Proteomic analysis of cap-dependent translation identifies LARP1 as a key regulator of 5'TOP mRNA translation. Genes Dev. 2014, 28, 357-371. [CrossRef]

106. de Turris, V.; Di Leva, G.; Caldarola, S.; Loreni, F.; Amaldi, F.; Bozzoni, I. TOP promoter elements control the relative ratio of intron-encoded snoRNA versus spliced mRNA biosynthesis. J. Mol. Biol. 2004, 344, 383-394. [CrossRef]

107. Mourtada-Maarabouni, M.; Hasan, A.M.; Farzaneh, F.; Williams, G.T. Inhibition of human T-cell proliferation by mammalian target of rapamycin (mTOR) antagonists requires noncoding RNA growth-arrest-specific transcript 5 (GAS5). Mol. Pharmacol. 2010, 78, 19-28. [CrossRef]

108. McMahon, M.; Contreras, A.; Holm, M.; Uechi, T.; Forester, C.M.; Pang, X.; Jackson, C.; Calvert, M.E.; Chen, B.; Quigley, D.A.; et al. A single H/ACA small nucleolar RNA mediates tumor suppression downstream of oncogenic RAS. eLife 2019, 8. [CrossRef]

109. Fritz, J.M.; Lenardo, M.J. Development of immune checkpoint therapy for cancer. J. Exp. Med. 2019, 216, 1244-1254. [CrossRef]

110. Warner, W.A.; Spencer, D.H.; Trissal, M.; White, B.S.; Helton, N.; Ley, T.J.; Link, D.C. Expression profiling of snoRNAs in normal hematopoiesis and AML. Blood Adv. 2018, 2, 151-163. [CrossRef]

111. Zhong, F.; Zhou, N.; Wu, K.; Guo, Y.; Tan, W.; Zhang, H.; Zhang, X.; Geng, G.; Pan, T.; Luo, H.; et al. A SnoRNA-derived piRNA interacts with human interleukin-4 pre-mRNA and induces its decay in nuclear exosomes. Nucleic Acids Res. 2015, 43, 10474-10491. [CrossRef] [PubMed]

112. Motzer, R.J.; Banchereau, R.; Hamidi, H.; Powles, T.; McDermott, D.; Atkins, M.B.; Escudier, B.; Liu, L.F.; Leng, N.; Abbas, A.R.; et al. Molecular Subsets in Renal Cancer Determine Outcome to Checkpoint and Angiogenesis Blockade. Cancer Cell 2020, 38, 803-817 e804. [CrossRef] [PubMed]

113. Toden, S.; Zumwalt, T.J.; Goel, A. Non-coding RNAs and potential therapeutic targeting in cancer. Biochim. Biophys. Acta Rev. Cancer 2021, 1875, 188491. [CrossRef]

114. Yuan, S.; Wu, Y.; Wang, Y.; Chen, J.; Chu, L. An Oncolytic Adenovirus Expressing SNORD44 and GAS5 Exhibits Antitumor Effect in Colorectal Cancer Cells. Hum. Gene Ther. 2017, 28, 690-700. [CrossRef] [PubMed]

115. Cui, L.; Nakano, K.; Obchoei, S.; Setoguchi, K.; Matsumoto, M.; Yamamoto, T.; Obika, S.; Shimada, K.; Hiraoka, N. Small Nucleolar Noncoding RNA SNORA23, Up-Regulated in Human Pancreatic Ductal Adenocarcinoma, Regulates Expression of Spectrin Repeat-Containing Nuclear Envelope 2 to Promote Growth and Metastasis of Xenograft Tumors in Mice. Gastroenterology 2017, 153, 292-306.e2. [CrossRef] 